\title{
PENANAMAN KARAKTER DERMAWAN MELALUI SEDEKAH
}

\author{
Fifi Nofiaturrahmah \\ Sekolah Tinggi Agama Islam Negeri (STAIN) Kudus \\ e-mail:fifinofiaturrahmah@gmail.com
}

\begin{abstract}
Generosity is a character, a character rarely found in a person. In Islam teaches its people to have the character or the character of generosity with the aim to have a sense of gratitude towards the favors of Allah, manifesting high social sensitivity, and the realization of a community that likes to help. Generosity is a character or character that is rarely found in a person not everyone has a generous character, especially in adolescents today. Teenagers are currently more likely and busy with his world and his youth. Teenagers are currently less sensitive to the environment around them, especially in the environment that needs one $>$ s help. One institution in instilling one character is the character of generosity through the activities of infak and alms. Through the methods, strategies, approaches and forms of planting through various activities both in daily habituation activities.
\end{abstract}

Keywords: Planting, Character, Generosity, Infak and Alams 


\section{Pendahuluan}

Agama Islam mengajarkan pemeluknya untuk saling menyayangi dan mengasihi terhadap sesamanya. Setiap orang memiliki karakter yang berbeda-beda ada yang memiliki karakter dermawan ada pula yang kikir. Seseorang yang berjiwa pengasih dan penyayang dirinya akan dekat dengan Allah dan Rasulullah dan semua orang disekitarnya. Sebaliknya, seseorang yang tiada belas kasih sayang terhadap sesama, apalagi terhadap orangorang lemah, maka dia akan jauh dengan Allah, Rasulullah serta orang di sekitarnya. Sehingga pada akhirnya mereka juga jauh dengan surga dan dekat dengan neraka. Hidup ini terasa indah jika semua orang dapat saling mengasihi satu sama lain.

Dalam dunia pendidikan penanaman kedermawanan sangatlah penting ditanamkan pada setiap jenjang pendidikan terutama pada peserta didik agar kelak menjadi manusia yang memiliki kepekaan sosial. Bangsa yang maju dan berhasil itu ditentukan oleh kualitas dan karakteristik bangsa itu sendiri, melalui sistem pendidikan yang mencetak setiap (output) pesrta didik selain, pintar secara akademis juga pintar dalam pengaplikasikannya, cerdas secara lahiriyah dan batiniyah.

Penanaman karakter kedermawanan bisa melalui metode keteladanan, nasihat, pembiasaan atau pemantauan, dan hukuman. Serta melalui pendekatan yaitu perilaku sosial dan perkembangan moral kognitif. Serta strategi yang digunakan melalui kegiatan rutin, spontan, keteladanan dan pengkondisian. Serta dalam bentuk penanaman yaitu peduli terhadap diri sendiri, peduli terhadap teman dan adik kelas, peduli terhadap guru dan peduli terhadap lingkungan sosial. Yang mana penanaman karakter kedermawanan melalui kegiatan infak dan sedekah melalui kegiatan yaitu kegiatan sehari-hari seperti kegiatan infak harian, baksos, kerja bakti, menjenguk ketika ada teman yang sakit atau terkena musibah. 
Orang yang suka bersedekah adalah orang yang benar pengakuan imannya. Menurut syariat, pengertian sedekah sama dengan pengertian infaq, termasuk juga hukum dan ketentuanketentuannya. Hanya saja, jika infaq berkaitan dengan materi, sedekah memiliki arti lebih luas dari sekedar material, misal senyum itu sedekah. Dari hal ini yang perlu diperhatikan adalah jika seseorang telah berzakat tetapi masih memiliki kelebihan harta, sangat dianjurkan sekali untuk berinfaq atau bersedekah dalam beberapa ungkapan al-Quran.

Undang-undang No. 20 tahun 2003 tentang Sistem Pendidikan Nasional Bab II Pasal 3 menyebutkan bahwa: Pendidikan nasional berfungsi mengembangkan kemampuan dan membentuk watak serta peradaban bangsa yang bermartabat dalam rangka mencerdaskan kehidupan bangsa, bertujuan untuk berkembangnya potensi peserta didik agar menjadi manusia yang beriman dan bertakwa kepada Tuhan Yang Maha Esa, berakhlak mulia, sehat, berilmu, cakap, kreatif, mandiri, dan menjadi warga negara yang demokratis serta bertanggung jawab (Muhammad bin Salih, 2008: 2) Islam memerintahkan kepada umatnya untuk suka memberi, dan Rasulullah SAW merupakan teladan bagi umat Islam untuk mencintai perilaku berderma kepada siapa saja.

Islam mengajarkan kepada umatnya untuk memiliki jiwa dermawan dengan tujuan untuk menjernihkan jiwa seseorang, mewujudkan kepekaan sosial yang tinggi, tenggang rasa terhadap saudara yang fakir, kesempatan penting untuk mengingat karunia Allah dari berbagai nikmat yang diberikan-Nya. Hidup sederhana dan tidak berlebih-lebihan dan tidak bermewah-mewahan, serta untuk menyalurkan harta dijalan Allah semata berharap rida Allah SWT. Selain itu syariat Islam bertujuan untuk mewujudkan keridhaan dan kelapangan hati seseorang yang menerima sedekah, perekat ukuwah Islamiyah, terciptanya masyarakat yang dinamis, gemar tolong-menolong. Hal itu menekankan bahwa Islam adalah agama yang mempunyai satu tujuan, satu landasan, dan satu kewajiban. 
Proses penanaman karakter kedermawan ini dimulai sejak dini dengan berbagai metode seperti keteladanan, atau contoh perbuatan, dengan nasihat, permainan, cerita, pembiasaan tingkah laku, pembiasaan perkataan, Perhatian, pemantauan dan lain-lain. Kegiatan penanaman aspek kepekaan hati terhadap orang lain dan sesamanya menjadikan hati yang mutmainah, melatih kesadaran diri, peduli sosial terutama pada orang yang membutuhkan.

Kegiatan infak dan sedekah ini merupakan kegiatan berupa infak harian yang bersifat lunak (sunah) dan infak jumat (wajib) dan dalam memberikan infaq tidak ditentukan nominalnya, yang mana setelah dana terkumpul diserahkan ke bagian bendahara. Dana yang telah terkumpul dialokasikan untuk siswa yang terkena musibah, siswa sakit, kematian baik dari siswa maupun wali siswa, sumbangan sosial berupa sembako bagi janda tua dan kaum dhuafa, bagi masyarakat yang tidak mampu (fakir miskin) dan kaum lemah.

\section{Pembahasan}

\section{Penanaman karakter kedermawanan}

Penanaman yaitu proses, cara, perbuatan menanam, menanami, atau menanamkan (Pusat Bahasa Departemant Pendidikan Nasional, 2007: 1134). Karakter adalah sifat atau halhal yang memang sangat mendasar yang ada pada diri seseorang. Hal-hal yang sangat abstrak yang ada pada diri seseorang. Sering orang menyebutnya dengan tabiat atau perangai (Abdul Majid dan Dian Andayani, tt.: 12). Kedermawanan dalam Kamus Lengkap bahasa Indonesia yaitu Kebaikan hati terhadap sesama manusia, kemurahan hati (Qonita Alya, tt.: 152). Dermawan artinya dengan iklas memberi, menolong atau rela berkorban di jalan Allah baik dengan harta bahkan dengan jiwa dan raganya baik berupa berbentuk uluran tangan untuk bersedekah, infak, zakat, dan sebagainya (Muhammad Hamid, 2012: 19).

Dalam bahasa Inggris, karakter disebut dengan istilah character yang berarti mengukir, melukis, memahatkan, atau menggoreskan. Berbeda dengan kamus bahasa Inggris, Kamus Bahasa Indonesia mengartikan kata "karakter" dengan tabiat, 
sifat-sifat kejiwaan, akhlak atau budi pekerti yang membedakan seseorang dengan yang lain. Merujuk pada pengertian kebahasaan dalam kamus bahasa Indonesia tersebut, karakter dapat dipahami sebagai huruf, angka, ruang, simbol khusus yang dapat dimunculkan pada layar dengan papan ketik (Pusat Bahasa Departemen Pendidikan Nasional, 2008: 682). Artinya, orang berkarakter adalah orang yang berkepribadian, berperilaku, bersifat, bertabiat, atau berwatak.

Doni Koesoema memahami bahwa karakter sama dengan kepribadian. Kepribadian dianggap sebagai "ciri, atau karakteristik, atau gaya, atau sifat khas dari diri seseorang yang bersumber dari bentukan-bentukan yang diterima dari lingkungan, misalnya lingkungan keluarga pada masa kecil dan juga bawaan seseorang sejak lahir (Doeni Koesoema, 2007: 980)." Definisi karakter menurut Pritchard adalah sesuatu yang berkaitan dengan kebiasaan hidup individu yang bersifat menetap dan cenderung positif (I Pritchard, 1988: 467).

Karakter itu berkaitan dengan kekuatan moral, berkonotasi 'positif', bukan netral. Jadi, 'orang berkarakter' adalah orang yang mempunyai kualitas moral (tertentu) positif. Dengan demikian, pendidikan membangun karakter, secara implisit mengandung arti membangun sifat atau pola perilaku yang didasari atau berkaitan dengan dimensi moral yang positif atau baik, bukan yang negatif atau buruk. Hal ini didukung oleh Peterson dan Seligman yang mengaitkan secara langsung character strength dengan kebajikan. Character strength dipandang sebagai unsurunsur psikologis yang membangun kebajikan (virtues) (Raka Gede, et.al, 2007: 5).

Salah satu kriteria utama dari character strength adalah bahwa karakter tersebut berkontribusi besar dalam mewujudkan sepenuhnya potensi dan cita-cita seseorang dalam membangun kehidupan yang baik, yang bermanfaat bagi dirinya, orang lain, dan bangsanya.

Istilah pendidikan karakter mulai dikenalkan sejak tahun 1900-an. Thomas Lickona disebut-sebut sebagai pengusungnya, terutama ketika ia menulis buku yang berjudul The Return of Character Education dan kemudian disusul buku berikutnya, yakni 
Educating for Character. How Our School Can Teach Respect and Responsibility. Melalui buku-buku Thomas Lickona tersebut, dunia Barat menyadari betapa pentingnya pendidikan karakter.

Menurut Lickona, pendidikan karakter mencakup tiga unsur pokok, yaitu mengetahui kebaikan (knowing the good), mencintai kebaikan (desiring the good), dan melakukan kebaikan (doing the good). Senada dengan Lickona, Frye mendefinisikan pendidikan karakter sebagai, A national movement creating schools that foster ethical, responsible, and caring young people by modelling and teaching good character through an emphasis on universal values that we all share (Mike Frye, et.al., 2002: 2).

Pendidikan karakter adalah sebuah gerakan nasional yang dibuat sekolah untuk mengembangkan etika, tanggung jawab dan menjaga anak muda dengan modeling pembelajaran dan karakter yang baik melalui penekanan pada nilai-nilai universal yang kita semua bagi. Menurut Maragustam Siregar Pendidikan karakter ialah mengukir dan mempatrikan nilai-nilai ke dalam diri peserta didik melalui pendidikan, endapan pengalaman, pembiasaan, aturan dan rekayasa lingkungan, dan pengorbanan dipadukan dengan nilai-nilai intrinsik yang sudah ada dalam diri peserta didik sebagai landasan dalam berpikir, bersikap dan perilaku secara sadar dan bebas (Maragustam Siregar, 2015: 245).

Berdasarkan pengertian di atas, dapat dipahami bahwa kedermawanan merupakan karakter yang mencerminkan kebaikan hati terhadap sesama, kemuran hati, upaya tolong menolong dengan tujuan meringankan beban orang lain dengan memberi, menginfakan harta yang dimiliki dengan tujuan memberikan rasa bahagia kepada orang lain dengan rasa ikhlas rela berkorban di jalan Allah SWT.

Dalam hal ini, yang dimaksud dengan penanaman karakter kedermawanan adalah cara atau proses dalam menanamkan karakter kedermawanan pada peserta didik yang didalamnya ada berbagai metode pendidikan yang dilakukan sekolah dalam menanamkan karakter kedermawanan pada peserta didik.

Anak yang terlahir ke dunia dalam keadaan bersih atau suci, namun dalam diri anak tersebut juga terdapat potensi-potensi diri untuk berkembang lebih baik ataupun sebaliknya sesuai 
lingkungan yang mendidiknya. Diperlukan sosok yang mampu membina dan mengarahkan anak agar berkembang menjadi pribadi yang baik. Anak merupakan anugerah terindah dalam kehidupan dimana dalam pola perkembangannya diperlukan asuhan yang tepat oleh orang tua.

Satu hal yang perlu digarisbawahi adalah, bahwa setiap manusia mempunyai kecenderungan untuk berkarakter apik. Kecenderungan manusia ini dapat dibuktikan dalam kesamaan konsep pokok karakter dalam setiap peradaban bahkan zaman. Sekadar contoh, tidak ada peradaban yang menganggap baik perbuatan bohong, penindasan, keangkuhan, kekerasan dan lain sebagainya. Demikian pula sebaliknya, tidak ada peradaban yang menganggap buruk perbuatan menghormati kedua orang tua, keadilan, kejujuran, dan pemaaf sebagai hal yang baik. Dan, semua kebaikan tersebut telah ditegaskan dalam kitab suci alQuran. Dengan demikian, kebaikan sejati hanyalah dari Allah SWT. Karakter kebaikan sesungguhnya telah melekat dalam diri manusia secara fitrah. Dengan bekal kemampuan inilah manusia mampu membedakan antara kebaikan dan keburukan, dan kebermanfaat dengan ketidakbermanfaatan (Sayid Fuad al-Bahi, 1975: 347). Oleh karena itu pentingnya menanamkan karakter kedermawanan.

Seorang anak penting mengetahui hal-hal yang berkaitan dengan pendidikan akhlak, sebab dalam menjalani kehidupan dibutuhkan seperangkat tata cara dan etika, baik dalam hubungannya dengan individu yang bersangkutan, masyarakat luas, atau makhluk lainnya, bahkan dengan sang Pencipta. Oleh karena itu, materi akhlak adalah membicarakan nilai sesuatu perbuatan menurut ajaran agama, membicarakan sifat-sifat terpuji dan tercela dari kaca mata agama. Dengan demikian dipahami bahwa pendidikan akhlak mempunyai cakupan yang sangat luas, baik berkaitan dengan individu, masyarakat, alam dan Allah SWT (Irwan Prayitno, 2003).

Pendidikan akhlak terletak pada penanaman nilai-nilai ajaran agama yang tercermin dan terwujud dalam tingkah laku dan budi pekerti seorang anak dalam kehidupan sehari-hari. Hal ini menunjukkan bahwa dalam seluruh aspek kehidupan, manusia senantiasa membutuhkan aturan agar tidak merugikan 
orang lain dan tercipta suasana yang damai dan tentram. Seorang anak yang telah dididik untuk bertingkah laku yang baik akan mampu berkomunikasi dan berinteraksi dengan lingkungan yang luas. Sebaliknya, jika anak tidak dikenalkan pada upaya pembentukan akhlak yang terpuji, maka anak akan hidup tanpa aturan dan cenderung pada perbuatan yang menyimpang. Dengan demikian, pendidikan akhlak adalah bekal yang amat berguna bagi seorang anak.

Dalam pandangan Zakiah Daradjat, akhlak itu sendiri adalah kelakuan yang timbul dari hasil perpaduan antara hati nurani, pikiran, perasaan bawaan, dan kebiasaan yang menyatu membentuk suatu kesatuan tindak akhlak yang dihayati dalam kenyataan hidup keseharian. Dari kelakuan itu lahirlah perasaan moral (moralesence)yang terdapat di dalam diri manusia sebagai fitrah, sehingga ia mampu membedakan mana yang baik dan mana yang jahat, mana yang bermanfaat dan mana yang tidak berguna, mana yang cantik dan mana yang buruk (Zakiah Daradjat, 1995: 10). Menurut Soedijarto pendidikan moral (akhlak) lahirnya manusia terdidik yang memiliki rasa tanggung jawab melalui pengintegrasian nilai dengan penahapan yang secara hierarkhis memiliki klasifikasi kognitif, afektif, evaluatif, dan konatif (Soedijarto, 1993: 75).

Dengan demikian pendidikan akhlak diharapkan dapat menyentuh kawasan internalisasi (pendalaman) dan karakterisasi (penghayatan). Keteladanan merupakan salah satu metode pendidikan yang diterapkan Rasulullah dan paling banyak pengaruhnya terhadap keberhasilan menyampaikan misi dakwahnya. Ahli pendidikan banyak yang berpendapat bahwa pendidikan dengan teladan merupakan metode yang paling berhasil guna. Hal ini disebabkan karena secara psikologis anak adalah seorang peniru yang ulung. Murid-murid cenderung meneladani gurunya dan menjadikannya sebagai tokoh identifikasi dalam segala hal.

Proses pendidikan Islam dilalui dan dialami anak mulai dari tahap kognisi, yaitu pengetahuan dan pemahaman anak terhadap ajaran agama dan nilai-nilai yang terkandung dalam ajaran Islam. Selanjutnya adalah afeksi, yaitu proses internalisasi ajaran dan nilai agama ke dalam diri anak melalui penghayatan 
dan keyakinan. Penghayatan dan keyakinan anak menjadi kokoh jika dilandasi oleh pengetahuan dan pemahamannya terhadap ajaran dan nilai-nilai agama Islam. Melalui tahap afeksi akan tumbuh motivasi dalam diri anak untuk tergerak mengamalkan dan mentaati ajaran Islam (tahap psikomotorik) yang telah terinternalisasi dalam dirinya. Dengan demikian akan terbentuk manusia muslim yang beriman, bertakwa, dan berakhlak mulia (Muhaimin, 2001: 78).

Disamping itu, dalam menerapkan pendidikan karakter sesuai ajaran agama Islam yaitu dengan memberikan contoh tauladan kepada anak tentang kejujuran, kedisiplinan, kataatan, toleransi, dan kasih sayang akan memunculkan karakter anak yang terbuka terhadap setiap masalah yang dihadapi dalam kehidupannya. Pembinaan karakter anak yang dilakukan dengan kasih sayang dan lemah lembut akan berdampak positif bagi perkembangannya. Islam juga melarang keras membina karakter anak melalui pukulan dan amarah yang berlebihan serta kebencian (Irwan Prayitno \& Datoak Rajo Bandaro, 2004: 487).

Socrates berpendapat bahwa tujuan paling mendasar dari pendidikan adalah untuk membuat seseorang menjadi good and smart. Dalam sejarah Islam, Rasulullah Muhammad SAW, sang Nabi terakhir dalam ajaran Islam, juga menegaskan bahwa misi utamanya dalam mendidik manusia adalah untuk mengupayakan pembentukan karakter yang baik (good character). Berikutnya, ribuan tahun setelah itu, rumusan tujuan utama pendidikan tetap pada wilayah serupa, yakni pembentukan kepribadian manusia yang baik. Tokoh pendidikan Barat yang mendunia seperti Klipatrick, Lickona, Brooks, Goble seakan menggemakan kembali gaung yang disuarakan Muhammad SAW. Bahwa moral, akhlak atau karakter adalah tujuan yang tak terhindarkan dari dunia pendidikan. Begitu juga dengan Marthin Luther King menyetujui pemikiran tersebut dengan mengatakan, "Intelligence plus character, that is the true aim of education". Kecerdasan plus karakter, itulah tujuan yang benar dalam pendidikan (Abdul Majid \& Dian Andayani, 2010: 30). 


\section{Kegiatan infak dan sedekah}

Infak berasal dari kata anfaga yang berarti mengeluarkan sesuatu (harta) untuk suatu kepentingan (Suhadi, 2012: 11). Sedangkan Sedekah berasal dari kata shadaqoh yang berarti suatu pemberian yang diberikan oleh seorang muslim kepada orang lain secara spontan dan suka rela tanpa dibatasi oleh waktu dan jumlah tertentu. Sedekah berarti suatu pemberian yang diberikan oleh seseorang sebagai kebajikan yang mengharap ridha Allah SWT dan pahala semata (Aqilah Selma Amalia, 2014: 140).

Infak dan sedekah yang dimaksud dalam tulisan ini yaitu kegiatan infak harian dan infak Jumat yang dilakukan oleh peserta didik dan kegiatan ini dinamakan dengan kegiatan koin amal. Peserta didik dalam beramal dengan menggunakan uang, baik logam atau pun uang kertas dan tidak ditentukan nominalnya. Dalam kegiatan ini, salahsatunya menanamkan kedermawanan, melalui kegiatan ini dana dialokasikan seperti untuk kegiatan infaq harian atau infak Jumat, bakti sosial, dan kegiatan sosial.

Pandangan al-Ghazali anak hendaknya dibiasakan dalam perilaku akhlak yang terpuji dan perbuatan yang baik serta dijauhkan dari perbuatan yang buruk dan rendah. Mendidik akhlak anak menurutnya merupakan pekerjaan yang bernilai tinggi dan paling penting, sebab anak adalah amanat Allah bagi orang tuanya di mana hatinya bersih suci bagaikan mutiara yang cemerlang dan jiwanya sederhana yang kosong dari segala ukiran. Anak-anak itu akan menerima segala sesuatu yang diukirkan kepadanya serta condong kepada sesuatu yang mengotorinya (Muhammad Munîr Mursi, 1987: 241).

Selain itu, Ibn Qayyim al-Jauziyah juga menyoroti tentang pentingnya akhlak. Ia mengatakan bahwa di antara hal yang amat dibutuhkan di dalam mendidik anak ialah masalah akhlaknya. Anak akan tumbuh sesuai dengan apa yang dibiasakan kepadanya oleh sang pendidik semasa sang anak masih kecil. Oleh karena itu, banyak dijumpai orang yang akhlaknya menyimpang dari kebenaran, yang disebabkan oleh pendidikan di mana ia dibesarkan. Terjadinya kemerosotan akhlak yang banyak terdapat di kalangan anak-anak, sebagian besar penyebabnya 
ialah akibat salah asuh dari pihak orang tuanya (Ibnu al-Qayyim, tt.: 240- 244).

Pernyataan ini tampak menegaskan bahwa baik buruknya akhlak tergantung pada baik tidaknya pendidikan yang diperoleh anak. Tugas pendidik untuk melatih anak semenjak kecil agar dibiasakan berlaku jujur, menghormati orang lain, mencintai orang lain, dan mampu bergaul dengan baik. Dengan demikian pendidikan akhlak pada dasarnya bermuara pada pembentukan sikap dan tindak tanduk yang baik sesuai dengan nilai-nilai ajaran agama.

Akhlak adalah sebuah pilar kehidupan yang sangat berharga dan tetap dibutuhkan sepanjang zaman. Di Indonesia misalnya, kurikulum pendidikan tidak terlepas dari pembentukan aspek moral atau akhlak. Aspek moral atau akhlak dapat ditemukan dalam paket pendidikan agama. Artinya, pendidikan akhlak adalah menjadi bagian dari pendidikan agama (Zakiah Daradjat, 1996: 70).

Menurut T. Ramli, pendidikan karakter memiliki esensi dan makna yang sama dengan pendidikan moral dan pendidikan akhlak. Tujuannya adalah membentuk pribadi anak, supaya menjadi manusia yang baik, warga masyarakat, dan warga negara yang baik. Adapun kriteria manusia yang baik, warga masyarakat yang baik, dan warga negara yang baik bagi suatu masyarakat atau bangsa, secara umum adalah nilai-nilai sosial tertentu, yang banyak dipengaruhi oleh budaya masyarakat dan bangsanya. Oleh karena itu, hakikat dari pendidikan karakter dalam konteks pendidikan di Indonesia adalah pedidikan nilai, yakni pendidikan nilai-nilai luhur yang bersumber dari budaya bangsa Indonesia sendiri, dalam rangka membina kepribadian generasi muda (Jamal Ma' mur Asmani, 2011: 32).

Menurut Anis Mata dalam bukunya yang berjudul Membentuk Karakter Muslim menyebutkan beberapa kaidah pembentukan karakter sebagai berikut:

Pertama, Kaidah kebertahapan, artinya proses perubahan, perbaikan, dan pengembangan harus dilakukan secara bertahap. Seorang anak dalam hal ini tidak bisa dituntut untuk berubah sesuai yang diinginkan secara tiba-tiba dan instant, namun ada 
tahapan-tahapan yang harus dilalui dengan sabar dan tidak terburu-buru. Adapun orientasi dari kegiatan ini adalah terletak pada proses dan bukan pada hasil. Sebab yang namanya proses pendidikan itu tidak langsung dapat diketahui hasilnya akan tetapi disini membutuhkan waktu yang lama sehingga hasilnya nanti paten.

Kedua, Kaidah Kesinambungan, artinya perlu adanya latihan yang dilakukan secara terus menerus. Seberapapun kecilnya porsi latihan yang penting adalah pada kesinambungannya. Sebab proses yang berkesinambungan inilah yang nantinya membentuk rasa dan warna berfikir seseorang yang lama-lama akan menjadi kebiasaan dan seterusnya menjadi karakter pribadi anak yang khas dan kuat.

Ketiga, Kaidah Momentum, artinya mempergunakan berbagai momentum peristiwa untuk fungsi pendidikan dan latihan. Misalnya menggunakan bulan Ramadhan untuk mengembangkan sifat sabar, kemauan yang kuat, kedermawanan dan lain-lain.

Keempat, Kaidah Motivasi Intrinsik, artinya karakter anak akan terbentuk secara kuat dan sempurna jika didorong oleh keinginan sendiri bukan merupakan paksaan dari orang lain. Proses merasakan sendiri dan melakukan sendiri adalah sebuah proses yang penting. Hal ini sesuai dengan kaidah umum bahwa mencoba sesuatu akan lebih berbeda hasilnya antara yang dilakukan sendiri dengan hanya yang bisa dilihat dan diperdengarkan saja. Oleh karena itu pendidikan harus menanamkan motivasi yang kuat dan lurus serta melibatkan aksi fisik yang nyata.

Kelima, Kaidah Pembimbing, artinya perlunya bantuan orang lain untuk mencapai hasil yang lebih baik daripada dilakukan seorang diri. Pembentukan karakter ini tidak bisa dilakukan tanpa seorang guru atau pembimbing. Hal ini karena kedudukan seorang guru selain untuk memantau dan mengevaluasi perkembangan anak-anak guru juga berfungsi sebagai unsur perekat, tempat curhat dan sarana tukar pikiran bagi anak didiknya (Muhammad Anis Mata, 2003: 67-70). 


\section{Simpulan}

Berdasarkan uraian di atas tentang penanaman karakter kedermawanan melalui kegiatan infak dan Penanaman karakter kedermawanan yang mana kegiatan infak terdiri dari kegiatan infak harian dan Jumat serta kegiatan mengunjungi jika teman yang sakit. Kegiatan sedekah terdiri dari kegiatan bakti sosial, bulan bersih bagi warga atau kerja bakti dan bulan gizi bagi peserta didik. Kegiatan ini sudah terangkum dan tersusun baik. Penanaman karakter kedermawanan dilakukan dengan menggunakan metode keteladanan, pembiasaan, nasihat, perhatian atau pemantauan, dan hukuman atau sanksi. Strategi yang digunakan yaitu dengan pengembangan budaya sekolah seperti dalam bentuk kegiatan rutin, spontan, keteladanan dan pengkondisisan. Pendekatan yang dilakukan oleh pihak sekolah atau dewan guru dalam menanamkan Pendidikan karakter dermawan dilakukan dengan cara pendekatan pertama yaitu perilaku sosial. Kedua pendekatan perkembangan moral kognitif.

\section{Daftar Pustaka}

Abdul Majid \& Dian Andayani, Pendidikan Karakter Perspektif Islam, PT. Remaja Rosdakarya, Bandung, 2010.

Aqilah Selma Amalia, Kisah Nyata Sukses Membuka Pintu Rezeki Dengan 7 Amal Ajaib, Abata Press, Klaten, 2014.

Irwan Prayitno \& Datoak Rajo Bandaro, Anakku Penyejuk Hatiku, Pustaka Tarbiatuna, Bekasi, 2004.

Irwan Prayitno, Membangun Potensi Anak, Cet. ke-2, Mitra Grafika, Jakarta, 2003.

Jamal Ma'mur Asmani, Buku Panduan Internalisasi Pendidikan Karakter Di Sekolah, Diva Press, Yogyakarta, 2011.

Maragustam Siregar, Filsafat Pendidikan Islam: Menuju Pembentukan Karakter Menghadapi Arus Global, Kurnia Kalam Semesta, Yogyakarta, 2015. 
Muhaimin, Paradigma Pendidikan Islam, Remaja Rosdakarya, Bandung, 2001.

Muhammad Anis Mata, Membentuk Karakter Cara Islami, AlI'tishom Cahaya Umat, Jakarta, 2003.

Muhammad bin Salih, Fatwa-fatwa Zakat, Darus Sunnah, Jakarta, 2008.

Muhammad Hamid, Dahsyatnya Menyantuni Anak Yatim Dan Fakir Miskin, Tugu Publisher, Yogyakarta, 2012.

Muhammad Munîr Mursi, al-Tarbiyah al-Islâmiyyah Ushûluhâ wa Tathawwuruhâ fî Bilâd al-Islâmiyyah, Dâr al-Ma>ârif, Mesir, 1987.

Pusat Bahasa Departemant Pendidikan Nasional, Kamus Besar Bahasa Indonesia, Balai Pustaka, Jakarta, 2007.

Qonita Alya, Kamus Lengkap Bahasa Indonesia, Indah Jaya Pratama, Bandung, tt.

Sayid Fuad Al-Bahi, Asas al-Nafsiyyah li al-Namuwwi min alThufulah wa al-Syuyuhah, Dar al-Fikr al-'Arabi, Kairo, 1975.

Suhadi, Dahsyatnya Sedekah Tahajud, Duha dan Santuni Anak Yatim, Shahih, Surakarta, 2012.

Yusuf Qardhawi. Hukum Zakat, Studi Komparatif Mengenai Status Dan Filsafat Zakat Berdasarkan Qur'an Dan Hadits, Litera AntarNusa, Jakarta, 1987. 